\title{
Subcellular localization of $\alpha$-tubulin and opsin mRNA in the goldfish retina using digoxigenin-labeled cRNA probes detected by alkaline phosphatase and HRP histochemistry
}

\author{
Linda K. Barthel and Pamela A. Raymond * \\ Department of Anatomy and Cell Biology, University of Michigan, Ann Arbor, MI 48109 (USA) \\ (Received 2 March 1993) \\ (Revised version received 9 June 1993) \\ (Accepted 10 June 1993)
}

Key words: In situ hybridization; Digoxigenin; cRNA; Cone opsin mRNA; Horseradish peroxidase; Alkaline phosphatase; Photoamplification

This paper describes a method for non-radioactive in situ hybridization providing subcellular localization of $\mathrm{mRNA}$ in $3 \mu \mathrm{m}$ cryosections. We used two alternative colorimetric reactions to detect digoxigenin-labeled cRNA probes: alkaline phosphatase and HRP (horseradish peroxidase). With some probes the signal with the alkaline phosphatase reaction was intense, and diffusion of the reaction product was noticeable. Using HRP-conjugated antibodies improved the resolution but decreased the sensitivity of the signal. Photoamplification of the HRP reaction product increased the contrast and improved the sensitivity of the technique.

\section{Introduction}

The technique of in situ hybridization has become widespread in the study of gene regulation in many tissues including the central nervous system (cf., Cimino et al., 1989). Radioactive probes have been used in the majority of the work, but non-radioactive probes are becoming increasingly popular. The advantages of non-radioactive probes are well known and include safety of laboratory personnel, avoidance of radioactive waste disposal, increased stability of the probe, improved cellular resolution, shorter processing time, and sensitivity equivalent to radioactive detection (Singer et al., 1986; Polak and

\footnotetext{
* Corresponding author: Dr. P.A. Raymond, Department of Anatomy and Cell Biology, University of Michigani, Ann Arbor, MI 48109-0616, USA. Tel.: (313) 747-0811; FAX: (313) 763-1166.
}

McGee, 1990). Non-radioactive probes also offer the advantage that they can be used in wholemounts of embryos so that the expression pattern of a specific gene can be visualized directly (Hemmati-Brivanlou et al., 1990; Coutinho et al., 1992; Püschel et al., 1992). The resolution obtained with radioactive probes can be improved by using ${ }^{3} \mathrm{H}$-labeled UTP in place of ${ }^{35} \mathrm{~S}$ (Singer et al., 1986; Baldino and Chesselet, 1989; Polak and McGee, 1990; Porello et al., 1991), but the major limitation of ${ }^{3} \mathrm{H}$ is the long exposure times (days or even weeks) required to get a detectable signal. With the digoxigenin-labeled cRNA probes, detected either with alkaline phosphatase- or HRP-conjugated antibodies, the whole procedure, including both hybridization and detection, requires a maximum of 3 days. In addition, the conditions used in the hybridization of cRNA probes are compatible with immunohistochemistry (Biffo et al., 1992; Wahle and Beckh, 1992) which allows for the simultaneous detection of specific proteins and the mRNA of interest. 
Many papers have been published describing methods for in situ hybridization on neural tissues using digoxigenin-labeled cRNA probes detected with alkaline phosphatase-conjugated anti-digoxigenin antibodies (Hemmati-Brivanlou, 1990; Springer et al., 1991; Biffo et al., 1992; Coutinho et al., 1992; Püschel et al., 1992; Boehringer Mannheim Non-radioactive in situ Hybridization Application Manual, 1992). The purpose of this paper is to describe an alternative method using horseradish peroxidase (HRP)-conjugated digoxigenin antibodies combined with photoamplification of the HRP color product (Vaney, 1993). We demonstrate that compared to alkaline phosphatase, the HRP method provides improved resolution of the signal at some cost in sensitivity.

\section{Material and methods}

\section{General methods and tissue preparation}

All labware used in the steps prior to hybridization is specified for prehybridization use only. The labware is thoroughly washed, rinsed in a solution of $0.1 \%$ diethylpyrocarbonate (DEPC: Sigma, St. Louis, MO), and then autoclaved. Glassware is baked at $210^{\circ} \mathrm{C}$ for a minimum of 24 $\mathrm{h}$ prior to use. Gloves are worn throughout all procedures prior to hybridization. All solutions are made in de-ionized water mixed with $0.1 \%$ DEPC for $0.5-2 \mathrm{~h}$ and then autoclaved.

Adult goldfish, $4-5 \mathrm{~cm}$ total length, were anesthetized in $0.02 \%$ methane tricaine sulfonate (Sigma, St. Louis, MO), and decapitated. For radial retinal sections the eyes were enucleated, four incisions were made in the cornea, and the vitreous was digested with hyaluronidase $(200 \mathrm{U} /$ $\mathrm{ml})$ and collagenase $(350 \mathrm{U} / \mathrm{ml})$ in phosphatebuffered saline (PBS: $0.276 \mathrm{~g} / 1 \mathrm{NaH}_{2} \mathrm{PO}_{4} \cdot \mathrm{H}_{2} \mathrm{O}$; $1.14 \mathrm{~g} / 1 \mathrm{Na}_{2} \mathrm{PO}_{4} ; 8.76 \mathrm{~g} / 1 \mathrm{NaCl} ; 0.187 \mathrm{~g} / 1 \mathrm{KCl}$; $\mathrm{pH} 7.4$ ) for $5-10 \mathrm{~min}$ at room temperature. The eyecups were then fixed for $0.5 \mathrm{~h}$ at room temperature with $4 \%$ paraformaldehyde in $0.1 \mathrm{M}$ phosphate buffer, pH 7.4, with $5 \%(0.15 \mathrm{M})$ sucrose. The lens was gently removed and the eye was bisected along the dorsoventral axis and placed back into the fixative for an additional 0.5 h. For tangential retinal sections, the eyecup was opened by making an incision around the outermost perimeter of the iris, the retina was flushed away from the pigmented epithelium with a saline solution $(0.9 \% \mathrm{NaCl})$, and the optic nerve was cut with microscissors to free the retina. Relaxing cuts were made in the retina to allow it to lay flat, and prior to fixation it was incubated in the enzymatic mixture as described above. The retina was then fixed with gentle rotation under a siliconized coverslip for $1 \mathrm{~h}$ at room temperature.

Following fixation the tissue was rinsed 3 times for $10 \mathrm{~min}$ each in $0.1 \mathrm{M}$ phosphate buffer with $5 \%$ sucrose. After the final buffer rinse the tissue was prepared for $3 \mu \mathrm{m}$ cryosections as described previously (Barthel and Raymond, 1990). Following cryoprotection overnight in phosphate buffer, pH 7.4 with $20 \%$ sucrose $(0.6 \mathrm{M})$, and infiltration for $0.5 \mathrm{~h}$ in a solution of $20 \%$ sucrose in phosphate buffer, $\mathrm{pH} 7.4$ / Tissue Tek OCT embedding medium (2:1) (Miles, Kankakee IL), the tissue was embedded in the same mixture and frozen in isopentane cooled with liquid nitrogen. The sections were placed on poly-L-lysine-coated slides, placed in a vacuum desiccant chamber for $2-24 \mathrm{~h}$ at room temperature and stored with desiccant at $-90^{\circ} \mathrm{C}$.

\section{Probe synthesis}

We obtained from K. Nakanishi (Johnson et al., 1993) goldfish cDNA clones containing the coding region for the red cone opsin, GFred, and the green cone opsin, GFgr-2, and we used these clones to generate cRNA probes for in situ hybridization. The goldfish cDNA clones had been subcloned into the EcoRI site of pBluescript II SK (Stratagene, La Jolla, CA). The cDNA template for GFgr-2 is 565 bp long, and for GFred the template is $1.8 \mathrm{~kb}$ long. Preparation of the plasmids was done by alkaline extraction (Birnboim and Doly, 1979), and concentration with a Centricon 30 microconcentrator (Amicon, Beverly, MA). The plasmids with inserts were linearized by digestion with either HindIII or $X b a I$ endonuclease, purified through an Elutip-d minifiltration column (Schleicher and Schuell, Keene, NH) and concentrated with a Centricon 30 microconcentrator. We also obtained a cDNA 
clone for goldfish $\alpha$-tubulin in pSP73, linearized with ClaI endonuclease (Promega, Madison, WI) from D. Goldman (Hieber et al., 1992). The cDNA template for the goldfish $\alpha$-tubulin is approximately 500 bp long.

Runoff transcription of the RNA probes was done according to the manufacturer's specifications (The Genius System User's Guide for Filter Hybridization, Boehringer Mannheim, Indianapolis, IN) with a few modifications. Microcentrifuge tubes were siliconized prior to use. Approximately $1-1.5 \mu \mathrm{g}$ of template DNA was transcribed from the $\mathrm{T} 7$ promoter site of the GFred clone to generate the probe identical ('sense') to the mRNA target. Transcription from the T7 promoter of the GFgr-2 clone generated a probe complementary ('antisense') to the mRNA target. Correspondingly, transcription from the $\mathrm{T} 3$ promoter site generated the antisense probe for GFgr-2 and the sense probe for GFred. Transcription from the $\mathrm{T} 7$ promoter site of pSP73 generated an antisense probe to the $3^{\prime}$ untranslated region of the goldfish $\alpha$-tubulin. After $1 \mathrm{~h}$ of incubation at $37^{\circ} \mathrm{C}$ another $40 \mathrm{U}$ of RNA polymerase was added to each reaction mixture and transcription of the probes continued for a total of $2 \mathrm{~h}$. The RNA probes were precipitated at $-90^{\circ} \mathrm{C}$ for $24 \mathrm{~h}$ and resuspended in $100 \mu \mathrm{l}$ of DEPC-treated water. Aliquots containing $2 \mu \mathrm{g}$ of the RNA probe were placed into siliconized microcentrifuge tubes and stored at $-20^{\circ} \mathrm{C}$. Due to variable and incomplete transcription, probe length ranged from about $500 \mathrm{bp}$ to $1.8 \mathrm{~kb}$ as determined by gel electrophoresis.

\section{Prehybridization treatment of the tissue}

Procedures for prehybridization are modified from a method described by Simmons (1989). The slides were removed from the freezer and allowed to air dry at room temperature. The tissue was rehydrated in an ethanol series $(95 \%, 70 \%$, $50 \%)$ and $2 \times \mathrm{SSC}(0.3 \mathrm{M} \mathrm{NaCl}, 0.03 \mathrm{M}$ sodium citrate in DEPC-treated deionized water) for 1 min each. Digestion with $0.01 \mathrm{mg} / \mathrm{ml}$ proteinase K (Boehringer Mannheim, Indianapolis, IN) was performed at $37^{\circ} \mathrm{C}$ in $0.1 \mathrm{M}$ Tris-base (Boehringer Mannheim, cat. no. 604-205), pH 8.0, with $50 \mathrm{mM}$ EDTA, for $2 \mathrm{~min}$. The slides were quickly rinsed in room temperature DEPC-treated water and then incubated at room temperature in $0.1 \mathrm{M}$ triethanolamine (Sigma, St. Louis, MO) $\mathrm{pH} 8.0$, for $3 \mathrm{~min}$, followed by a $10-\mathrm{min}$ rinse in $0.1 \mathrm{M}$ triethanolamine with $0.25 \%$ acetic anhydride (Sigma; St. Louis, MO). The tissue was dehydrated, 1 min each, in $2 \times \mathrm{SSC}$, in an ethanol series of $50 \%, 70 \%, 95 \%$, and 2 times in $100 \%$ ethanol, and allowed to dry at room temperature for at least $1 \mathrm{~h}$.

\section{Hybridization}

Prior to use the aliquot containing the RNA probe was heated to $65^{\circ} \mathrm{C}$ for $10 \mathrm{~min}$ and then immediately placed on ice. The following reagents were added in order to the tube containing $2 \mu \mathrm{g}$ or $0.5 \mu \mathrm{g}$ of the RNA probe: $5 \mu \mathrm{l}$ of $1.0 \mathrm{M}$ Tris- $\mathrm{HCl}, \mathrm{pH} 7.5,250 \mu \mathrm{l}$ of $100 \%$ formamide, 30 $\mu l$ of $5.0 \mathrm{M} \mathrm{NaCl}, 1 \mu 1$ of $0.5 \mathrm{M}$ EDTA, $100 \mu$ l of $50 \%$ dextran sulfate, $50 \mu \mathrm{l}$ of $10 \%$ blocking reagent (Boehringer Mannheim, Cat. no. 1096$176)$ in maleate buffer $(100 \mathrm{mM}$ maleic acid, $\mathrm{pH}$ $7.5,150 \mathrm{mM} \mathrm{NaCl}$ ), and DEPC-treated water to bring the final volume to a total of $500 \mu 1$. Approximately $60 \mu \mathrm{l}$ of the hybridization solution containing the probe was pipetted onto a siliconized coverslip (Wanaka et al., 1990). The slides were inverted onto the coverslips and the edges were sealed with DPX mountant (BDH Laboratory Supplies, Poole, UK). Tissue was hybridized overnight on a warming tray at $55^{\circ}-56^{\circ} \mathrm{C}$.

\section{Post-hybridization}

The DPX was removed from the slides with forceps and the coverslips were soaked off in $2 \times$ SSC for $0.5 \mathrm{~h}$ at room temperature. The slides were washed in fresh $2 \times$ SSC for an additional $0.5 \mathrm{~h}$, then in $50 \%$ formamide in $2 \times \mathrm{SSC}$, heated to $65^{\circ} \mathrm{C}$, for $0.5 \mathrm{~h}$, followed by two 10 -min $2 \times$ SSC washes at $37^{\circ} \mathrm{C}$. The buffer for RNase treatment (10 mM Tris, pH 7.5, $1 \mathrm{mM}$ EDTA, $0.5 \mathrm{M}$ $\mathrm{NaCl}$ ) was preheated to $37^{\circ} \mathrm{C}$ and $0.02 \mathrm{mg} / \mathrm{ml}$ of RNase A (Boehringer Mannheim, Indianapolis, IN) was added, and the slides were incubated for $0.5 \mathrm{~h}$. The RNase treatment was stopped by rinsing the slides in the same buffer, without RNase, heated to $65^{\circ} \mathrm{C}$, for $0.5 \mathrm{~h}$. 


\section{Immunocytochemical detection of cRNA probe}

Non-specific binding of the digoxigenin antibody was blocked by incubating the slides in $2 \times$ SSC with $0.05 \%$ Triton X-100 (Sigma, St. Louis, MO) and $1 \%$ blocking reagent, for $2-3 \mathrm{~h}$ at room temperature. The slides were rinsed twice, $5 \mathrm{~min}$ each, in maleate buffer. A ring was wiped dry around the edge of the slide without allowing the sections to dry, and a PAP pen (Research Products International, Prospect, IL) was used to draw a barrier ring around the sections. The anti-digoxigenin Fab fragment antibodies were diluted in maleate buffer with $1 \%$ blocking reagent and $0.3 \%$ Triton $\mathrm{X}-100$, and $100-200$ $\mu l$ was plated on each slide. The antibody conjugated to alkaline phosphatase (Boehringer Mannheim, Cat. no. 1093-274) was diluted 1:3000 and the slides were incubated $3-5 \mathrm{~h}$ at room temperature in a humid chamber. The antibody conjugated to HRP (Boehringer Mannheim, Cat.
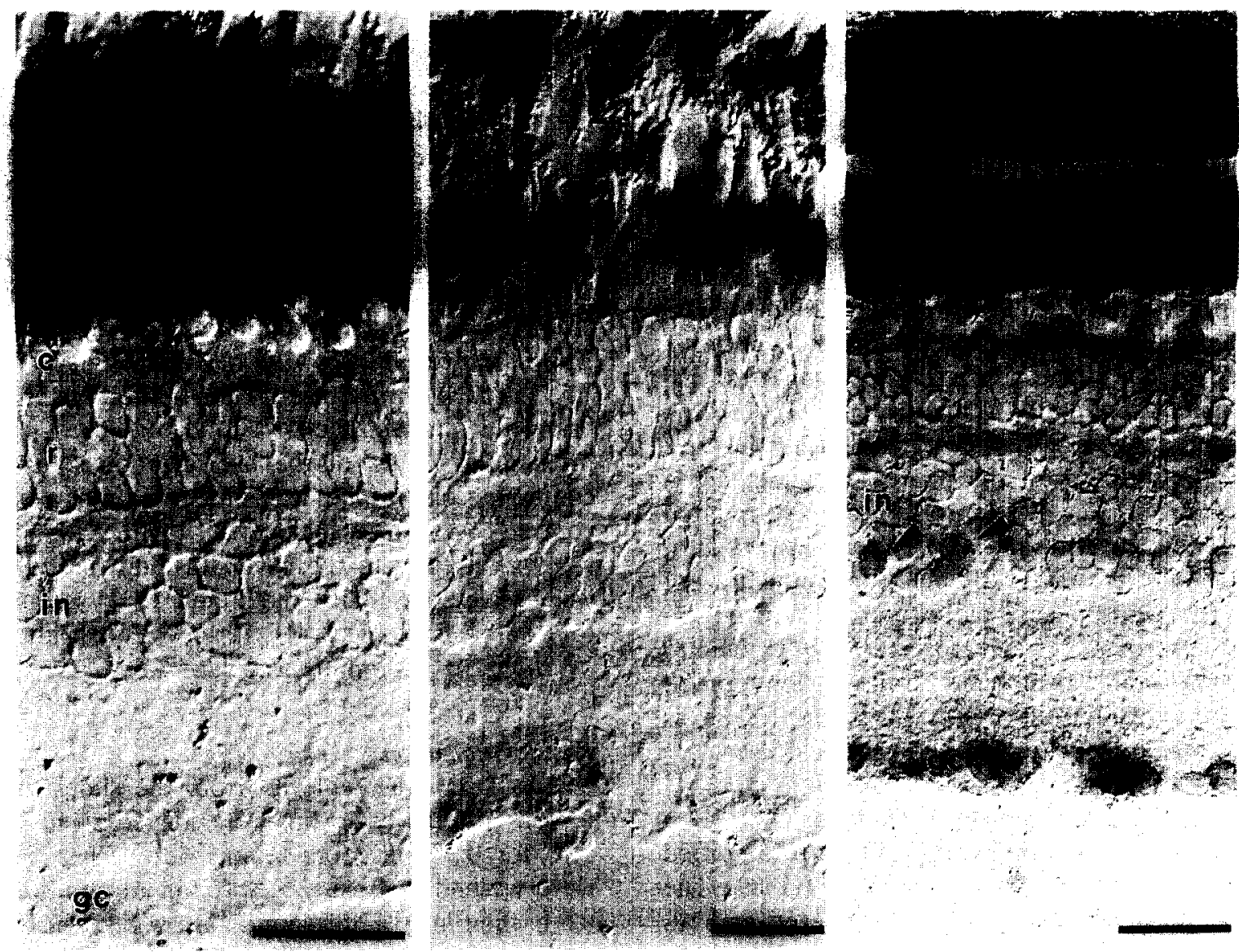

Fig. 1. A: radial cryosection of adult goldfish retina hybridized with the green cone opsin sense RNA probe; Nomarski interference contrast optics. The black granular structures at the top (arrowheads) are processes of retinal pigmented epithelial cells (RPE) that surround the photoreceptors. The neural retina is laminated and unstained. c, cones; $r$, rod nuclei; in, inner nuclear layer; gc, ganglion cell layer. Calibration bar $=20 \mu \mathrm{m}$ and applies to all panels. B: retinal section similar to that in (A) but from a region of the retina containing less pigment in the RPE; hybridized with the green cone opsin antisense RNA probe, visualized with alkaline phosphatase. Note the strong hybridization signal in the myoid region (arrowheads) connecting the ellipsoid (e) and nucleus (n). C: retinal section hybridized with the $\alpha$-tubulin antisense RNA probe, visualized with alkaline phosphatase. Note the granular reaction product in the somata of the ganglion cells (gc), and occasional amacrine cells (arrowheads) at the inner border of the inner nuclear layer (in). 
no. 1207-733) was diluted 1:20 and the slides were incubated in a humid chamber overnight at room temperature. Following incubation with the antibody the slides were washed twice in maleate buffer, $10 \mathrm{~min}$ each, and then washed in Boehringer Mannheim Genius kit 3 (Nucleic Acid Detection Kit) buffer 3 (100 mM Tris- $\mathrm{HCl}, \mathrm{pH}$ $9.5,100 \mathrm{mM} \mathrm{NaCl}, 50 \mathrm{mM}$ magnesium chloride) for $10 \mathrm{~min}$.

To detect the alkaline phosphatase-conjugated antibodies the slides were incubated overnight at room temperature in the chromogen substrate containing $45 \mu \mathrm{l}$ NBT (4-nitroblue tetrazolium chloride, $100 \mathrm{mg} / \mathrm{ml}$ in $70 \% \mathrm{v} / \mathrm{v}$ dimethylformamide, Boehringer Mannheim Cat. no. 1383213), and $35 \mu \mathrm{IX}$-phosphate, (5-bromo-4-chloro3-indolyl phosphate solution, $50 \mathrm{mg} / \mathrm{ml}$ in dimethylformamide, Boehringer Mannheim Cat. no. 1383-221) in buffer 3. To stop the color reaction the slides were washed for $0.5 \mathrm{~h}$ in $0.01 \mathrm{M}$ Tris- $\mathrm{HCl}, \mathrm{pH} 7.5$, with $1.0 \mathrm{mM}$ EDTA and $0.9 \%$ $\mathrm{NaCl}$. The tissue was coverslipped under glycerol diluted to $50 \%$ with the same buffer.

Prior to running the reaction to visualize the HRP-conjugated antibodies, the slides were rinsed in 0.1 M Tris buffer, $\mathrm{pH} 7.2$ (14.04 g Sigma Trizma hydrochloride, $1.34 \mathrm{~g}$ Sigma Trizma base in $1000 \mathrm{ml}$ of $\mathrm{dH}_{2} \mathrm{O}$ ) for $10 \mathrm{~min}$. The HRP-conjugated antibodies were visualized using hydrogen peroxide in the presence of $3,3^{\prime}$-diaminobenzidine tetrahydrochloride, DAB, (Sigma, St. Louis, MO). Equal volumes of $0.02 \%$ hydrogen peroxide, made in distilled water from a $30 \%$ stock, and $0.1 \%(1 \mathrm{mg} / \mathrm{ml}) \mathrm{DAB}$ in $0.1 \mathrm{M}$ Tris buffer, were mixed together. The slides were incubated in this reaction mixture in the dark for $15 \mathrm{~min}$. After sufficient color reaction was achieved, as determined by visual inspection through a microscope, the slides were washed in $0.1 \mathrm{M}$ Tris buffer, $\mathrm{pH} 8.2$, for $0.5 \mathrm{~h}$. Photochromic intensification of the DAB reaction product was performed as described by Vaney (1992). The slides were coverslipped under a solution of $0.02 \%$ NBT (Sigma, St. Louis, MO) in 0.1 M Tris buffer, pH 8.2. Photochromic intensification was achieved by placing the slides under a $40 \times$ objective on a Leitz Aristoplan epifluorescent microscope and illuminating the area of interest with a $100 \mathrm{~W}$ mercury light source filtered through a Leitz L3 (FITC) barrier filter. The rate of intensification was monitored visually and maximum contrast was achieved within $30 \mathrm{~s}$. The slides were washed in PBS, $\mathrm{pH} 7.4$, and coverslipped in a $50 \%$ glycerol solution in the same buffer. The edges of the coverslips were sealed with Permount (Fisher Scientific, Pittsburgh, PA) for storage. Photomicrography was done on a Leitz Aristoplan using differential interference contrast illumination.

\section{Results and discussion}

The background staining with digoxigenin riboprobes was minimal, and the RNA sense probes produced no signal (Fig. 1A). The opsin antisense RNA probes hybridized to a defined region of the cone photoreceptors, in the myoid or neck-like region connecting the ellipsoid and the nucleus (Fig. 1B). This is the expected subcellular localization, since electron microscopic descriptions of the morphology of goldfish cone photoreceptors have shown that the rough endoplasmic reticulum (rER) is localized to this region (Raymond, 1985). The red and green cone opsin probes hybridized to different morphological classes of cones (Raymond, 1993) which corresponded to previous identifications of cone types based on microspectrophotometric studies of the opsin pigments they contain (Stell and Hárosi, 1976).

The opsin mRNA is very abundant in photoreceptors, up to $0.06 \%$ of total retinal RNA in rat (Treisman et al., 1988), and the digoxigenin signal is correspondingly strong. Although we have not done a systematic analysis of the sensitivity of the colorimetric method as others have (Singer et al., 1986; Polak and McGee, 1990), we have used the same technique to examine tubulin mRNA, which is found in a different class of neurons in the goldfish retina and is expressed at lower abundance (Hieber et al., 1992). In situ hybridization studies with radiolabeled $\left({ }^{35} \mathrm{~S}\right)$ detection methods have shown that tubulin message is expressed predominately in retinal ganglion cells (Hieber et al., 1992), and we found a similar localization with digoxigenin-labeled riboprobes (Fig. 1C). Note that the signal is clearly localized to the 


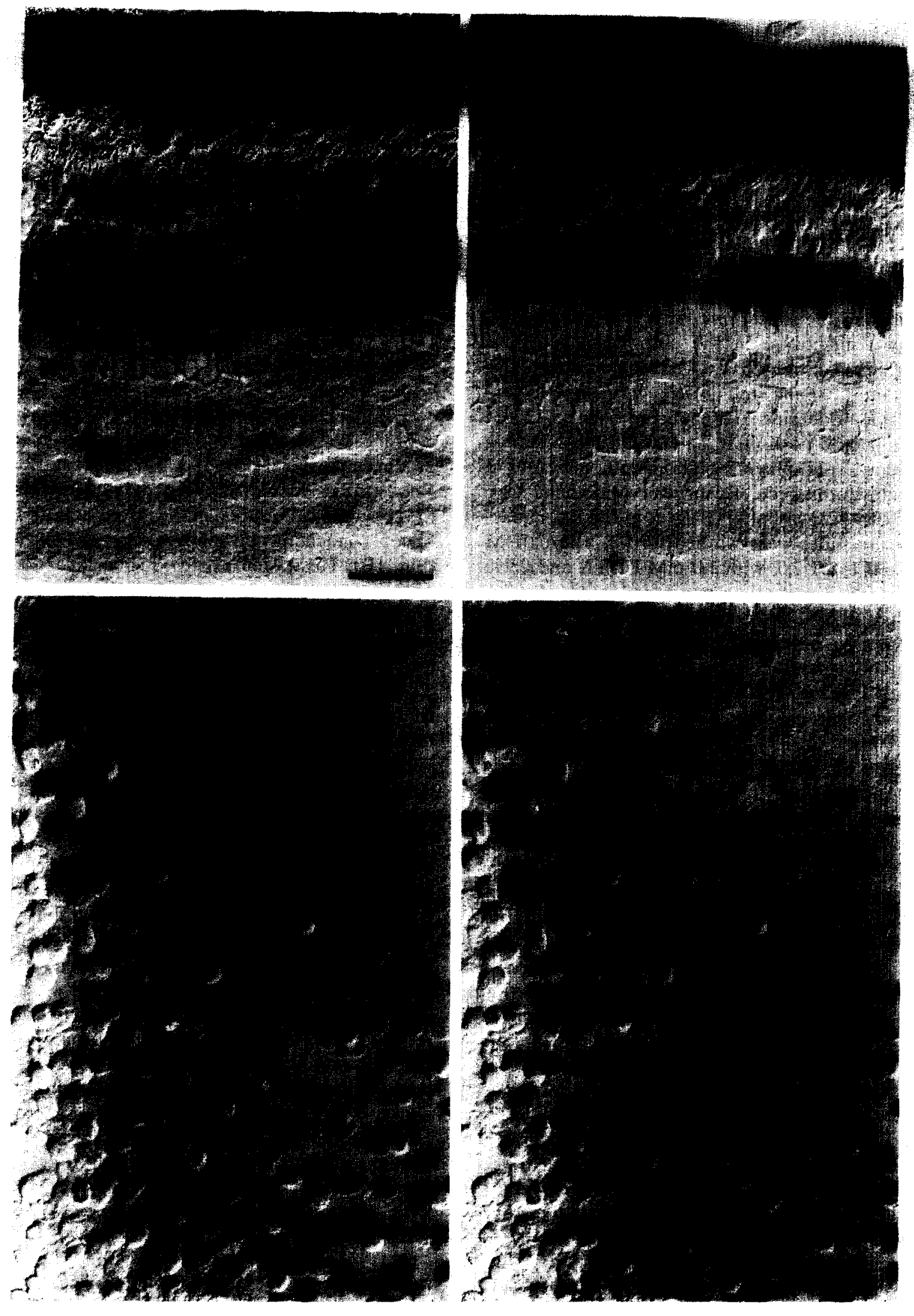


perinuclear cytoplasm, again corresponding to the pattern of rER distribution in these neurons (Peters et al., 1991).

With the alkaline phosphate reaction product, diffusion was often apparent. This was especially noticeable with the red opsin probe, which gave a very strong signal (Fig. 2A). Reduction of the probe strength from our standard $240 \mathrm{ng} / \mu \mathrm{l}$ to $60 \mathrm{ng} / \mu \mathrm{l}$, did little to improve the resolution. In an attempt to minimize diffusion of the reaction product we tried speeding up the reaction by heating the slides to $37^{\circ} \mathrm{C}$ for $2 \mathrm{~h}$ instead of letting the reaction proceed overnight at room temperature. Again there was little improvement. We therefore tried an alternative immunocytochemical visualization method with HRP-conjugated antibodies detected with DAB. The DAB reaction product, like the NBT product, is diffusible (Courtoy et al., 1983) and consequently there is some spread of the hybridization signal. However, the HRP reaction is faster, requiring only $15 \mathrm{~min}$, and proceeds at room temperature, so diffusion is minimized. Although the resolution with the HRP-DAB method was improved, the sensitivity of detection was much reduced we estimate by at least one order of magnitude. However, by taking advantage of a simple enhancement method for HRP-DAB reactions (Vaney, 1992), we were able to improve the contrast of the signal, while retaining the increased resolution. Fig. 2B illustrates the red cone opsin probe used in $2 \mathrm{~A}$, but visualized with the intensified $\mathrm{DAB}$ signal. Interestingly, the intensification method utilizes NBT, 1 of the 2 components of the substrate used in the alkaline phosphatase reaction. In the presence of light, NBT is reduced by the DAB reaction product and an insoluble black formazan product is formed (Altman, 1976). The reaction is very rapid, requiring only $30 \mathrm{~s}$, and is monitored visually. We believe that the speed of the reaction accounts for the limited diffusion of the formazan reaction product. Fig. 2C (before intensification) and 2D (afterward) illustrate the increase in contrast achieved by the intensification procedure.

In summary, we describe a method for detection of digoxigenin-labeled cRNA probes which gives superior subcellular localization of signal. Superior resolution was gained by replacing the alkaline phosphatase-conjugated antibody with the HRP-conjugated antibody. By using photoamplification the sensitivity of the signal was increased by enhancing the contrast of the HRP reaction product.

\section{Acknowledgements}

This work was supported by NIH Grant EY04318. The authors would like to acknowledge Dr. K. Nakanishi and Ms. Kathy Grant for their gracious gifts of cDNA clones for goldfish cone opsins, and Drs. V. Hieber and D. Goldman for the gift of the cDNA clone for goldfish $\alpha$-tubulin. Many thanks to Dr. F. Hoover for introducing us to in situ hybridization, and to Dr. D. Vaney for sharing his previously unpublished results on the photoamplification technique. Lastly many thanks go to Ms. Mary Ellen Rounsifer for high quality technical support.

Fig. 2. A: radial cryosection of a dark-adapted adult goldfish retina hybridized with the red cone opsin antisense RNA probe, visualized with alkaline phosphatase. Note the intense signal (arrowheads) in the myoid region of the cones adjacent to the nucleus (n). During dark adaptation the cone ellipsoids (e) migrate outward and the pigment in the processes of the retinal pigmented epithelial cell (RPE) retracts. Calibration bar $=20 \mu \mathrm{m}$ (and also applies to panel B). B: similar section hybridized with the same RNA probe as in (A) but visualized with the intensified HRP-DAB procedure. Note the increased resolution, the granularity of the reaction product, and the presence of signal in the perinuclear cytoplasm, giving the reactive cone profiles an hourglass shape (arrowheads). C and D: a single cryosection tangential to the retinal surface, through the layer of cone myoids, which are cut in cross-section. The section is shown before (C) and after (D) intensification of the DAB reaction product following hybridization with the green cone opsin antisense RNA probe. Note that some (arrowheads), but not all, of the cone myoids are reactive, as expected, since only some of the cones express the green opsin. Calibration bar $=20 \mu \mathrm{m}$. 


\section{References}

Altman, F.P. (1976) Tetrazolium salts and formazans. Prog. Histochem. Cytochem., 9: 1-56.

Baldino, F. Jr. and Chesselet, M. (1989) High-resolution in situ hybridization histochemistry. In: P.M. Coon (Ed.), Methods in Enzymology, Vol. 168, Academic Press, San Diego, CA, pp. 761-777.

Barthel, L.K. and Raymond, P.A. (1990) Improved method for obtaining $3-\mu \mathrm{m}$ cryosections for immunocytochemistry. $\mathbf{J}$. Histochem. Cytochem., 38: 1383-1388.

Biffo, S., Ludovica, V.C. and Fasolo, A. (1992) Double labeling with non-isotopic in situ hybridization and BrdU immunohistochemistry: calmodulin (CaM) mRNA expression in post-mitotic neurons of the olfactory system. J. Histochem. Cytochem., 40: 535-540.

Birnboim, H.C. and Doly, J. (1979) A rapid alkaline extraction procedure for screening recombinant plasmid DNA. Nucleic Acids Res., 7: 1513-1523.

Cimino, M., Cattabeni, F. and Weiss, B. (1989) In situ hybridization histochemistry as a tool to study gene expression and its regulation in the central nervous system. Pharmacol. Res., 21: 67-77.

Courtoy, P.J., Picton, D.H. and Gist Farquhar, M.G. (1983) Resolution and limitations of the immunoperoxidase procedure in the localization of extracellular matrix antigens. J. Histochem. Cytochem., 31: 945-951.

Coutinho, L.L., Morris, J. and Ivarie, R. (1992) In situ detection of low abundance transcripts of the myogenic factor qmf1 and myosin heavy chain protein in quail embryos. BioTechniques, 13: 722-724.

Hemmati-Brivanlou, A., Frank, D., Bolce, M., Brown, B.D., Sive, H.L. and Harland, R.M. (1990) Localization of specific mRNAs in Xenopus embryos by whole-mount in situ hybridization. Development, 110: 325-333.

Hieber, V., Agranoff, B.W. and Goldman, D. (1992) Targetdependent regulation of retinal nicotinic acetylcholine receptor and tubulin RNAs during optic nerve regeneration in goldfish. J. Neurochem., 58: 1009-1015.

Höltke, H.J. and Kessler, C. (1990) Non-radioactive labeling of RNA transcripts in vitro with the hapten digoxigenin (DIG); hybridization and ELISA-based detection. Nucleic Acids Res., 18: 5843-5851.

Johnson, R.L., Grant, K.B., Zankel, T.C., Boehm, M.F., Merbs, S.L., Nathans, J. and Nakanishi, K. (1993) Cloning and expression of goldfish opsin sequences. Biochemistry, 32: 208-214.

Peters, A., Palay, S.L. and Webster, H.deF. (1991) The Fine Structure of the Nervous System: Neurons and their Sup- porting Cells, 3rd edn., Oxford University Press, New York.

Polak, J.M. and McGee, JO'D. (1990) In situ Hybridization Principles and Practice. Oxford University Press, Oxford.

Porrello, K., Bhat, S. and Bok, D. (1991) Detection of interphotoreceptor retinoid binding protein (IRBP) mRNA in human and cone-dominant squirrel retinas by in situ hybridization. J. Histochem. Cytochem., 39: 171-176.

Püschel, A.W., Gruss, P. and Westerfield, M. (1992) Sequence and expression pattern of pax-6 are highly conserved between zebrafish and mice. Development, 114: 643-651.

Raymond, P.A. (1985) Cytodifferentiation of photoreceptors in larval goldfish: delayed maturation of rods. J. Comp. Neurol., 236: 90-105.

Raymond, P.A., Barthel, L.K., Rounsifer, M.E., Sullivan, S.A. and Knight, J.K. (1993) Expression of rod and cone visual pigments in goldfish and zebrafish: a rhodopsin-like gene is expressed in cones. Neuron, 10: 1161-1174.

Simmons, D.M., Arriza, J.L. and Swanson, L.W. (1989) A complete protocol for in situ hybridization of messenger RNAs in brain and other tissues with radio-labeled single-stranded RNA probes. J. Histotech., 12: 169-181.

Singer, R.H., Lawrence, J.B. and Villnave, C. (1986) Optimization of in situ hybridization using isotopic and nonisotopic detection methods. BioTechniques, 4: 230-250.

Springer, J.E., Robbins, E., Gwag, B.J., Lewis, M.E. and Baldino, F. (1991) Non-radioactive detection of nerve growth factor receptor (NGFR) mRNA in rat brain using in situ hybridization histochemistry. J. Histochem. Cytochem., 39: 231-234.

Stell, W.K. and Hárosi, F.I. (1976) Cone structure and visual pigment content in the retina of the goldfish. Vision Res., 16: $647-657$.

Treisman, J.E., Morabito, M.A. and Barnstable, C.J. (1988) Opsin expression in the rat retina is developmentally regulated by transcriptional activation. Mol. Cell Biol., 8: $1570-1579$.

Vaney, D.I. (1992) Photochromic intensification of diaminobenzidine reaction product in the presence of tetrazolium salts: applications for intracellular labeling and immunohistochemistry. J. Neurosci. Methods, 44: 217-223.

Wahle, P. and Beckh, S. (1992) A method of in situ hybridization combined with immunocytochemistry, histochemistry, and tract tracing to characterize the mRNA expressing cell types in heterogeneous neuronal populations. J. Neurosci Methods, 41: 153-166.

Wanaka, A., Johnson, Jr., E.M. and Milbrandt, J. (1990) Localization of FGF receptor mRNA in the adult rat central nervous system by in situ hybridization. Neuron, 5 : 267-281. 